\title{
VIRULENCE-ASSOCIATED CHARACTERISTICS OF ENTEROCOCCUS FAECALIS STRAINS ISOLATED FROM CLINICAL SOURCES
}

\author{
Márcia T. Furumura ${ }^{1}$; Patricia M.S. Figueiredo ${ }^{1}$; Gleize V. Carbonell ${ }^{2}$; Ana Lucia da Costa Darini ${ }^{3}$; Tomomasa Yano ${ }^{1 *}$ \\ ${ }^{1}$ Departamento de Microbiologia e Imunologia, Instituto de Biologia, Universidade Estadual de Campinas, Campinas, SP, Brasil; \\ ${ }^{2}$ Seção de Biologia Médica, Instituto Adolfo Lutz, Campinas, SP, Brasil; ${ }^{3}$ Departamento de Análises Clínicas, Toxicológicas e \\ Bromatológicas, Faculdade de Ciências Farmacêuticas de Ribeirão Preto, Universidade de São Paulo, Ribeirão Preto, SP, Brasil
}

Submitted: September 26, 2005; Returned to authors for corrections: January 11, 2006; Approved: April 19, 2006

\begin{abstract}
Thirty-two clinical isolates of Enterococcus faecalis were screened for virulence factors. Twenty-four (75\%) isolates produced hemolysin on Mueller-Hinton blood agar plates with sheep erythrocytes. However, the cell free heat-stable hemolysin was detected in all isolates (100\%) of E. faecalis when grown in BHI-GA (BHI medium supplemented with $1 \%$ glucose and $0.03 \%$ L-arginine), but not in BHI broth alone. Twenty-four isolates $(75 \%)$ produced caseinase and $23(71.9 \%)$ lipase, but none of the isolates produced gelatinase. Fifteen (46.9\%) culture filtrates caused rounding and membrane alterations with blebbing formation followed by death in HeLa and HEp-2 cells, but not in Vero cells. Thirteen isolates (40.6\%) agglutinated rabbit erythrocytes, but did not produce hemagglutination in other bloods, containing or not $1 \% \mathrm{D}$-manose. Sixteen (50\%) E. faecalis isolates adhered to HeLa cells and thirteen (40.6\%) to HEp-2 cells, but all isolates adhered to polypropylene microtiter plates, indicating that clinical E. faecalis possess the ability to form biofilm in vitro. All the isolates were resistant to the bactericidal action of normal serum and did not produce aerobactin. These findings suggest that adherence and consequently biofilm formation on ephitelial host cells are the first steps in the E. faecalis virulence and that hemolysin, lipase, caseinase and other virulence factors act as causative of human epithelial cell damages.
\end{abstract}

Key words: Enterococcus faecalis, virulence factors, hemolysin, proteases, lipase, cytotoxin, biofilm

\section{INTRODUCTION}

Infective endocarditis, sepsis and urinary tract infections are serious infections caused by Enterococcus faecalis, a microorganism which is now a pervasive clinical problem due to its resistance to most antibiotics (21). The involvement of $E$. faecalis in other types of infections is less clear, partly because of its frequent occurrence in mixed infections. However, the literature (7) has indicated that enterococci are emerging as prominent nosocomial pathogens in a variety of infections, including wound and genital infections, and bacteremia. The increasing clinical significance of enterococcal infections and the emergence of strains resistant to all available therapeutic alternatives have focused interest on factors possibly associated with the colonization and pathogenesis of enterococci (9).

Enterococcal virulence factors such as hemolysin (Hly), aggregation substance (Agg or AS) and an enterococcal protease, commonly referred to as gelatinase (Gel), have been suggested as possible contributors to the virulence of E. faecalis $(8,19)$. Some of these factors, including Cyl, Agg and Esp seem to be encoded on a large pathogenicity island (29).

Hemolysin is commonly produced by Gram-positive and Gramnegative bacteria and, in most cases, is considered to be a virulence factor, although its relative contribution to disease is variable among microbes and different host species (28). Due to the importance of Enterococcus species as nosocomial pathogens

*Corresponding Author. Mailing address: Departamento de Microbiologia e Imunologia, IB, Universidade Estadual de Campinas, Caixa Postal 6109. 13083-862, Campinas, SP, Brasil. Tel.: (+5519) 3788-6254, Fax: (+5519) 3788-6276. E-mail: tyano@unicamp.br 
and the increasing prevalence of antimicrobial resistance among enterococci, the identification and characterization of virulence factors, associated with enterococcal invasiveness and severity of disease, are important areas of investigation.

In the present study we investigated the virulence factors in E. faecalis strains isolated from different clinical sources.

\section{MATERIALS AND METHODS}

\section{Bacterial strains}

Thirty-two E. faecalis isolates were included in this study. They were collected in urine, blood, wounds or catheters from admitted patients (at least for five days) to the Hospital das Clínicas, Faculty of Medicine of Ribeirão Preto, University of São Paulo (USP), a Brazilian teaching hospital with 551 beds. The identification of all isolates was performed by API 20 Strep (bioMérieux) and PCR was performed to confirm species identification according to Dukta-Malen et al. (11). Control strains were E. faecalis NCTC 775, E. faecium NCTC 7171, E. gallinarum NCTC 12359, and E. casseliflavus NCTC 12361.

\section{Hemolytic assay}

The hemolytic activity of E. faecalis was assessed on blood agar plates prepared with Mueller-Hinton agar (MHA, Biolife, Italy) containing defibrinated sheep blood (final blood concentration, $5 \% \mathrm{v} / \mathrm{v}$ ), by observation of the hemolysis zone around colonies after incubation for $24 \mathrm{~h}$ at $37^{\circ} \mathrm{C}$ (4). Extracellular hemolysin was assayed on microplates using 100 $\mu \mathrm{L}$ of culture supernatant from E. faecalis grown on both $\mathrm{BHI}$ (Oxoid) and BHI supplemented with $1 \%$ glucose and $0.03 \% \mathrm{~L}$ arginine (3) (BHI-GA). The supernatants were serially diluted with $5 \mathrm{mM}$ phosphate buffered saline (PBS), $\mathrm{pH} 7.4$, mixed with an equal volume of a $1 \%$ sheep erythrocytes suspension and incubated at $37^{\circ} \mathrm{C}$ for $1 \mathrm{~h}$, followed by a further overnight incubation at $4^{\circ} \mathrm{C}$.

\section{Physico-chemical properties of the culture filtrates}

Heating the samples at $45^{\circ} \mathrm{C}, 60^{\circ} \mathrm{C}$ and $100^{\circ} \mathrm{C}$ for $30 \mathrm{~min}$ assessed the heat-stability of culture supernatants. The effect of proteolysis on activity was examined by treating the samples with trypsin, protease $\mathrm{K}$ and pepsin $(100 \mu \mathrm{g} / \mathrm{mL}$ each $)$ at $37^{\circ} \mathrm{C}$ for $60 \mathrm{~min}$ (18). Residual hemolytic activity was measured on microplates as described above.

\section{Protease production}

Casein hydrolysis was tested on MHA containing 3\% (w/v) skimmed milk, by streaking the plates with $10 \mu \mathrm{L}$ of each suspension followed by incubation at $37^{\circ} \mathrm{C}$ for $24 \mathrm{~h}$. The presence of a transparent zone around the colonies indicated caseinase activity (1). Gelatinase production was detected by inoculating the enterococci onto trypticase soya broth agar (TSA) containing 3\% gelatine (Oxoid). The appearance of turbid halos or zones around the colonies after incubation at $37^{\circ} \mathrm{C}$ for $24 \mathrm{~h}$ was considered to be a positive indication of gelatinase production (33).

\section{Lipase activity}

Lipase activity was determined as described by Gunn et al. (13): $10 \mu \mathrm{L}$ of bacterial suspension was placed into wells cut into $1 \%(\mathrm{w} / \mathrm{v})$ agarose in PBS containing $1 \%$ egg yolk and incubated at $37^{\circ} \mathrm{C}$ for $48 \mathrm{~h}$. The appearance of an opaque zone around colonies indicated lipolytic activity.

\section{Cytotoxicity assay}

Bacteria were cultured in $5 \mathrm{~mL}$ of BHI-GA at $37^{\circ} \mathrm{C}$ for $18 \mathrm{~h}$. The cultures were centrifuged $\left(6,000 \mathrm{x} \mathrm{g}, 15 \mathrm{~min}, 4^{\circ} \mathrm{C}\right)$ and the supernatants were filtered through $0.22 \mu \mathrm{m}$ membranes (Millipore, USA) prior to testing on Vero (African green monkey kidney), HeLa (human colon adenocarcinoma), or HEp-2 (human larynx epidermoid carcinoma) cells. The cells were grown in 96well tissue microplates with Eagle's minimal essential medium (EMEM, Nutricell) containing 10\% fetal calf serum (Nutricell) (27) and incubated in a $5 \% \mathrm{CO}_{2}$ atmosphere at $37^{\circ} \mathrm{C}$. The morphological changes were assessed using an inverted microscope (Nikon Instruments, Japan), after 24h incubation.

\section{Hemagglutination tests}

After centrifugation, the E. faecalis bacterial pellet was suspended in $5 \mathrm{mM}$ PBS, pH 7.4, to a final concentration of $10^{9}$ $\mathrm{CFU} / \mathrm{mL}$. An aliquot $(50 \mu \mathrm{L})$ of this suspension was added to an equal volume of a $2 \%(\mathrm{v} / \mathrm{v})$ suspension of horse, sheep or rabbit erythrocytes containing or not $1 \% \mathrm{D}$-mannose and the plates incubated at $37^{\circ} \mathrm{C}$ for $1 \mathrm{~h}$.

\section{Bacterial adhesion to cultured cells}

The ability of E. faecalis isolates to adhere to HEp-2 and HeLa cells was determined as previously described by Scaletsky et al. (30) with slight modifications. The cells were grown in MEM (Eagle's minimal essential medium) supplemented with $10 \%$ fetal calf serum in 24-well tissue culture microplates, in which sterile round coverslips were placed.

After 30 minutes incubation with the E. faecalis suspension at $37^{\circ} \mathrm{C}$, the monolayers were washed with sterile PBS and incubated again for 3 hours. Thereafter, the monolayers were washed with PBS, fixed with methanol for $10 \mathrm{~min}$ and stained by May-Grunwald and Giemsa for observation under bright field microscopy. Previously described criteria were used to determine the adhesion pattern (30).

\section{Biofilm formation assay}

E. faecalis $\left(10^{9} \mathrm{CFU} / 30 \mu \mathrm{L}\right)$ were cultured in $\mathrm{BHI}$ in 96-well microtiter plates at $37^{\circ} \mathrm{C}$ for $48 \mathrm{~h}$. After incubation, the broth was removed and added $0.5 \%$ crystal violet for five minutes. The plates were then washed with water and $200 \mu \mathrm{L}$ of $95 \%$ of 
ethanol was added. The biofilm formation was considered positive when an optical density at $570 \mathrm{~nm}$ (Labsystem Multiskan Bichromatic) was equal or major than 0.2 (34).

\section{Sensitivity to the bactericidal effect of normal serum}

The sensitivity of $E$. faecalis to the bactericidal effect of human normal serum was tested as described by Pelkonen and Finne (24). Bacteria grown in BHI for $18 \mathrm{~h}$ were diluted in PBS $\left(10^{9}\right.$ bacteria $\left./ \mathrm{mL}\right)$ and $175 \mu \mathrm{L}$ of the bacterial suspension and $175 \mu \mathrm{L}$ of PBS were pipetted into the wells of microtiter plates. One hundred microliters of serum (final concentration 36\%) were added to the wells and the plates were incubated at $37^{\circ} \mathrm{C}$. The absorbance at $630 \mathrm{~nm}$ was measured at $0,30,60,90,120$ and $180 \mathrm{~min}$. The plates were shaken before each measurement, to avoid the influence of bacterial sedimentation on the final absorbance. The strains were classified as resistant, intermediate or sensitive as suggested by Taylor (32).

\section{Aerobactin production}

The production of aerobactin was detected by cross feeding using Escherichia coli LG 1522 as an indicator. These bacteria express receptors for the ferric-aerobactin complex. Lawns of E. coli $\left(10^{9} \mathrm{CFU} / \mathrm{mL}\right)$ were spread on supplemented M9 minimal agar plates containing $\alpha, \alpha$-dipyridil, and $E$. faecalis was spotted onto the lawn. Aerobactin production was detected as a satellite halo which has grown after overnight incubation at $37^{\circ} \mathrm{C}$, as described by Carbonetti et al. (5).

\section{RESULTS}

\section{Hemolysin production}

Twenty-four (75\%) E. faecalis isolates showed hemolytic activity on Muller-Hinton agar containing sheep red blood cells (RBC) (Table 1). None of the culture supernatants from E. faecalis grown in BHI showed hemolytic activity, whereas all (100\%) supernatants from bacteria grown in BHI-GA hemolysed sheep RBC.

\section{Physico-chemical properties}

The hemolytic activity of $E$. faecalis culture supernatants was neither affected by heating nor by treatment with papain and proteinase K (data not shown).

\section{Lipase and Protease production}

Twenty-three E. faecalis isolates (71.9\%) showed lipase activity. Protease activity on skimmed milk was produced by 24 isolates $(75 \%)$ but no one showed gelatinase activity. (Table 1).

\section{Cytotoxicity assay}

Table 1 shows that 15 (46.9\%) culture supernatant filtrates from E. faecalis grown in BHI-GA caused rounding and cell

Table 1. Virulence properties of E. faecalis.

\begin{tabular}{|c|c|c|c|c|c|c|c|c|}
\hline \multirow[t]{2}{*}{ Isolates } & \multicolumn{3}{|c|}{ Hemolysin $^{\text {a) }}$ Cytotoxin ${ }^{\text {b) }}$} & \multirow{2}{*}{ Lipase $^{\text {c) }}$} & \multirow{2}{*}{ Protease $^{\mathrm{d})}$} & \multirow{2}{*}{$\mathrm{HA}^{\mathrm{e})}$} & \multicolumn{2}{|c|}{ Adhesion $^{\mathrm{f})}$} \\
\hline & Agar & SN & & & & & HEp-2 & $\mathrm{HeLa}$ \\
\hline EF1 & + & + & + & + & - & - & - & - \\
\hline EF2 & + & + & - & + & - & - & - & + \\
\hline EF3 & + & + & + & + & + & - & - & + \\
\hline EF5 & + & + & - & + & + & - & + & + \\
\hline EF6 & - & + & - & - & + & - & + & + \\
\hline $\mathrm{EF} 7$ & + & + & - & + & - & - & + & - \\
\hline $\mathrm{EF} 8$ & - & + & - & - & - & - & - & - \\
\hline EF9 & - & + & - & - & - & - & - & - \\
\hline EF11 & + & + & - & + & + & - & - & - \\
\hline $\mathrm{EF} 12$ & + & + & + & + & + & - & + & - \\
\hline $\mathrm{EF} 13$ & + & + & + & + & + & - & + & + \\
\hline EF14 & + & + & - & + & + & - & - & - \\
\hline EF15 & + & + & + & + & - & + & - & + \\
\hline EF16 & + & + & + & - & + & - & + & + \\
\hline $\mathrm{EF} 17$ & - & + & - & - & + & - & - & + \\
\hline EF18 & + & + & + & + & + & + & - & - \\
\hline EF19 & + & + & + & + & + & + & - & + \\
\hline $\mathrm{EF} 20$ & + & + & + & + & + & + & + & - \\
\hline $\mathrm{EF} 21$ & + & + & - & + & + & + & - & + \\
\hline $\mathrm{EF} 22$ & + & + & + & + & + & + & - & - \\
\hline $\mathrm{EF} 23$ & - & + & + & - & + & - & + & + \\
\hline $\mathrm{EF} 24$ & + & + & - & + & + & + & + & + \\
\hline $\mathrm{EF} 25$ & + & + & - & + & - & + & + & + \\
\hline $\mathrm{EF} 26$ & + & + & - & + & + & + & + & + \\
\hline $\mathrm{EF} 27$ & + & + & - & + & - & - & - & - \\
\hline $\mathrm{EF} 28$ & + & + & + & + & + & + & - & - \\
\hline EF29 & + & + & + & + & + & + & - & - \\
\hline EF30 & + & + & - & + & + & + & - & - \\
\hline EF31 & - & + & + & - & + & + & + & + \\
\hline EF32 & - & + & - & - & + & - & - & - \\
\hline EF33 & + & + & + & + & + & - & + & + \\
\hline EF34 & - & + & - & - & + & - & - & - \\
\hline
\end{tabular}

a) Hemolytic activities on agar plates and of culture supernatants (sn);

b) Cytotoxic activities to HeLa and HEp-2 cells;

${ }^{c)}$ Lipolytic activity;

d) Protease activity on skimmed milk and gelatin;

e) HA-agglutinating activity of rabbit erythrocytes;

f) Adhesion on HeLa and HEp-2 cells. 
membrane alterations by blebbing formation followed by death of HeLa (Fig. 1A) and HEp-2 cells (Fig. 1B) after a 24 hours period.

\section{Hemagglutination tests}

Table 1 shows that 13 E. faecalis isolates (40\%) agglutinated only rabbit erythrocytes in either absence or presence of $1 \% \mathrm{D}$ mannose. The hemagglutinating activity of $E$. faecalis isolates was completely inhibited by proteinase $\mathrm{K}(100 \mu \mathrm{g} / \mathrm{mL})$ but was unaffected by trypsin and pepsin (data not shown).

\section{Bacterial adhesion to cultured cells and biofilm formation}

Sixteen (50\%) E. faecalis isolates adhered to HeLa cells (data not shown) and thirteen (40.6\%) adhered to HEp-2 cells (Fig. 2). The 32 E. faecalis isolates formed biofilms on polypropylene plates (data not shown).

\section{Sensitivity to the normal serum bactericidal effect and aerobactin production}

All E. faecalis isolates were resistant to the bactericidal action of normal serum and none produced aerobactin (data not shown).
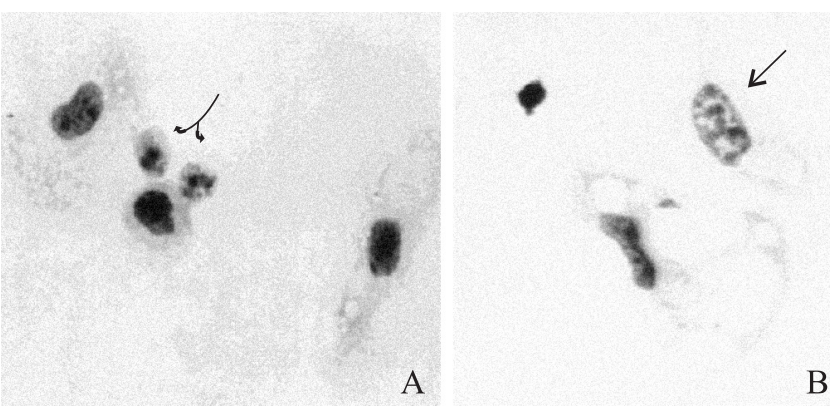

Figure 1. Cytotoxic activities to HeLa and HEp-2 cells. (A) HeLa cells and (B) HEp-2, treated with E. faecalis culture supernatant filtrates. The cell nuclei show different levels of compactness and pycnosis (arrowheads).

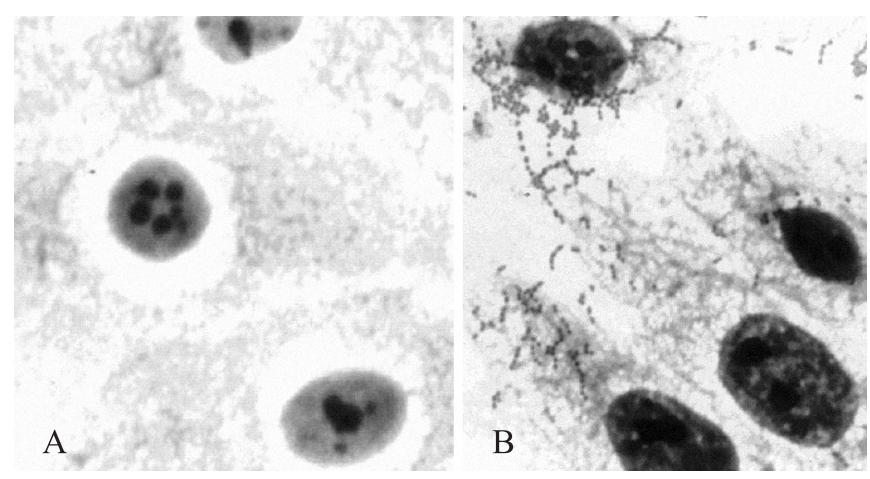

Figure 2. Adhesion to HEp-2 cells. (A) HEp-2 cells, control, (B) E. faecalis adhered to HEp-2 cells. $\mathrm{x} 430$.

\section{DISCUSSION}

Enterococci are Gram-positive cocci inhabitants of the gastrointestinal tract of many mammals, including humans, and are a frequent cause of a wide variety of infections involving the urinary tract, bloodstream, endocardium, abdomen, biliary tract and burn wounds $(7,21)$. Hemolysin-producing strains of E. faecalis are virulent in animal models and human infections and are associated with increasing infection severity (29).

In this study, all isolates have been previously analyzed by PFGE, the results revealing extensive heterogeneity and differentiation of all isolates into 32 types with Dice similarity coefficients between 20 and $92 \%$ (data not shown).

Of the clinical E. faecalis isolates, $75 \%$ produced the hemolytic halo around colonies on Mueller-Hinton sheep blood agar plates (Table 1). These findings differ from those of Miyazaki et al. (23) who detected hemolytic activity on several animal erythrocytes (except cow and sheep) included in BHI agar.

Vergis et al. (33) detected cell-free hemolysin on horse blood in $11 \%$ of E. faecalis. In this study, all E. faecalis isolates (100\%) exhibited extracellular hemolytic activity towards sheep erythrocytes only when grown in BHI-GA. Heating at $100^{\circ} \mathrm{C}$ did not abolish the hemolytic activity, indicating that the hemolysin is heat-stable. This activity was also resistant to proteolytic enzymes (data not shown). However, BHI culture supernatants did not show hemolytic activity on sheep blood suggesting that glucose and arginine are essential elements for heat-stable hemolysin production.

Gelatinase, an extracellular metalloprotease secreted by $E$. faecalis, hydrolyzes gelatin, collagen, and casein, and has been implicated as a virulence factor in animal models. The ability of this enzyme to hydrolyze collagens and certain bioactive peptides suggests its participation in the initiation and propagation of inflammatory processes involving E. faecalis (35). Vergis et al. (33) showed that $64 \%$ of E. faecalis isolated from patients with bacteremia, produced gelatinase, although no activity was found in the E. faecalis isolates described in this report. However, the data does suggest that the gelatin hydrolyzing activity is different from caseinase, detected in $75 \%$ of $E$. faecalis isolates (Table 1).

A variety of bacterial lipases, enzymes able to hydrolyze or synthesize triacylglycerols, have been described (15) but data relating these lipases to bacterial virulence factors are scarce. Among bacterial lipases, the enzymes from Staphylococcus epidermidis and Pseudomonas are well known but are yet to be defined as bacterial virulence factors (31).

The most prominent role of microorganism extracellular lipases may be the digestion of host cellular lipids for nutrient acquisition, which results in sticking to host tissue and neighboring cells (31). For Staphylococcus aureus it has been postulated that its lipase enhances adhesion by degrading host surface molecules, thereby liberating new receptors. Additionally, released free fatty acids (FFAs) might increase unspecific hydrophobic interactions, 
as it is assumed for Propionicbacterium acnes (22), the causative agent of acne vulgaris, a condition quite common during puberty. Undoubtedly, the biological role of lipases in infections by many microorganisms might be considered the most important step in bacterial infections $(6,15,31)$.

In this study, 23 E. faecalis clinical isolates (71.8\%) presented lipolytic activity. This frequency may be significant and suggests an important virulence property of E. faecalis in causing infections. However, no studies relating E. faecalis to lipases production were found in the literature.

Culture supernatants of some E. faecalis isolates (Table 1) caused rounding, a loss of intracellular junctions and the appearance of morphological features associated with apoptosis (Fig. 1). As a result, the cells became spherical and showed extensive surface blebbing. Similar morphological changes were reported by Falcón et al. (12), who observed that the cytotoxic enterotoxin produced by Aeromonas hydrophila caused cell detachment, cytoplasmatic disorganization and blebbing. Epithelial cell death by apoptosis may contribute to the action of this hemolysin. Therefore, further studies of this and other virulence factors in E. faecalis are necessary to establish their role in infections caused by the pathogen.

As shown in Table 1, only $13(40.6 \%)$ of the 32 E. faecalis isolates examined caused agglutination of rabbit erythrocytes in absence or presence of $1 \% \mathrm{D}$-mannose; this hemagglutination was inhibited by proteinase K (data not shown). Kurl et. al. (18) reported that hemagglutination caused by strains of Streptococcus suis was completely abolished by incubation with proteases and temperature-dependent. Activity was greater at $0^{\circ} \mathrm{C}$ than at $22^{\circ} \mathrm{C}$ or $37^{\circ} \mathrm{C}$, and rapidly lost at high temperatures. In contrast, as shown here, hemagglutination by isolates was unaffected by heating at $45^{\circ} \mathrm{C}, 60^{\circ} \mathrm{C}$ and $100^{\circ} \mathrm{C}$ (data not shown).

Potential enterococcal adherence factors involved in virulence include cell surface carbohydrates, homologues of cell surface adhesins found on a number of enterococcal species (20), that share characteristics with cell surface proteins of Grampositive bacteria and can act as a collagen adhesin (26) or as an aggregation substance (Agg). Bacterial adherence to host cells is the initial event in many infections (2). However, little information is available on the factors that promote adhesion of E. faecalis to host tissues (1). Kreft et al. (17) showed that 27.6\% of E. faecalis strains can adhere to human urinary tract epithelial cells. Guzmàn et al. (14) also demonstrated that clinical isolates of $E$. faecalis have a greater capacity to adhere to urinary tract epithelial cells and that ability of bacteria to adhere to host epithelial cells is an essential step in the pathogenicity of infections. In our study, sixteen E. faecalis isolates (50\%) adhered to HeLa cells (data not shown) and thirteen isolates (40.6\%) adhered to HEp-2 cells (Fig.2) but, did not show the pattern of adherence described for diarrheagenic Escherichia coli (30).

The ability to adhere to biomaterials is an important bacterial property, commonly implicated in the colonization and infection of catheters, but microbial adherence to non-biological surfaces depends on bacterial surface characteristics and on the nature of the inert material (15). Among the factors involved in this type of adherence are physico-chemical forces, such as polarity, van der Waal's forces and hydrophobic interactions (10) but factors involved in enterococcal adherence to biomaterials have not been well defined (19).

In the present study, we observed that all isolates of clinical E. faecalis showed ability to form biofilms on polystyrene plates, according to the methodologies described by Wakimoto et al. (34).

Bacteria associated with septicemia are frequently resistant to serum. Since the main role of the serum bactericidal system is to prevent microorganisms from invading and persisting in the blood, differences in the degree of bacterial susceptibility to serum determine whether a microorganism can infect and persist in a given organism (25). All the E. faecalis strains examined in this investigation were resistant to serum. The growth of bacteria in host tissue is limited, not only by host defense mechanisms, but also by the availability of iron, an essential factor for bacterial growth that functions mainly as a redox catalyst for proteins participating in oxygen and electron transport (25). E. faecalis did not produce aerobactin, indicating that these strains were not iron-bound to host proteins or cell-dependent.

Our results suggest that the main virulent property of clinical E. faecalis is adherence to epithelial host cells, leading to biofilm formation and consequently to the production of hemolysin, caseinase, lipase and other virulence factors, causative of human epithelial cell damages.

Further studies about virulence properties of E. faecalis are necessary to fully understand the pathogenicity of the bacteria. However, the findings in this study provide some new information in this direction.

\section{ACKNOWLEDGMENT}

The authors thank Ana Stella Menegon Degrossoli for technical assistance. We thank the Microbiology Laboratory of the Hospital das Clínicas de Ribeirão Preto, Universidade de São Paulo, Ribeirão Preto, Brazil, for kindly providing the $E$. faecalis strains. Financial support was provided by Coordenação de Aperfeiçoamento de Pessoal de Nível Superior (CAPES) and Conselho Nacional de Desenvolvimento Científico e Tecnológico (CNPq), Brazil.

\section{RESUMO}

\section{Características associadas à virulência de Enterococcus faecalis isolados de casos clínicos}

Foram estudados os fatores de virulência de trinta e duas amostras de Enterococcus faecalis, isolados de casos clínicos. Vinte e quatro amostras (75\%) produziram hemolisina em ágar 
sangue preparado com hemácias de carneiro. No sobrenadante da cultura em BHI nenhuma amostra produziu hemolisina, no entanto quando cultivadas em meio BHI suplementado com $1 \%$ de glucose e $0,03 \%$ de L-arginina (BHI-GA), $100 \%$ das amostras lisaram hemácias de carneiro. Vinte e quatro $(75 \%)$ amostras produziram caseinase e $23(71,9 \%)$ lipase, mas nenhuma amostra produziu gelatinase. Dezesseis $(46,9 \%)$ causaram arredondamento e alteração na membrana das células, com formação de vesículas e, em seguida, a morte das células HeLa e HEp-2. Treze amostras $(40,6)$ aglutinaram eritrócitos de coelhos, mas não aglutinaram outros eritrócitos na presença ou na ausência de $1 \%$ de D-manose. Dezesseis (50\%) aderiram em células HeLa e $13(40,6 \%)$ em células HEp-2, mas todas as amostras de E. faecalis aderiram na microplaca de polipropileno, indicando que E. faecalis isolados de casos clínicos possuem capacidade de formar biofilme "in vitro". Todos os isolados mostraram-se resistentes à ação bactericida do soro normal e não produziram aerobactina. Esses resultados sugerem que, inicialmente, a colonização ou infecção por E. faecalis ocorre pela aderência e formação de biofilme nas células epiteliais e a produção de hemolisina, lípase e caseinase pode atuar como fatores de virulência na infecção por E. faecalis.

Palavras-chave: Enterococcus faecalis, hemolisina, proteases, lípase, citotoxina, fatores de virulência

\section{REFERENCES}

1. Archimbaud, C.; Shankar, N.; Forestier, C.; Baghdayan, A.; Gilmore M.S.; Charbonné, F.; Joly, B. In vitro adhesive properties and virulence factors of Enterococcus faecalis strains. Res. Microbiol., 153, 7580, 2002.

2. Beachey, E.H. Bacterial adherence: adhesin-receptor interactions mediating the attachment of bacteria to mucosal surfaces. J. Infect. Dis., 143, 325-345, 1981.

3. Booth, M.C.; Bogie, C.P.; Sahl, H.G.; Siezen, R.J.; Hatter, K.L.; Gilmore, M.S. Structural analysis and proteolytic activation of Enterococcus faecalis cytolysin, a novel lantibiotic. Mol. Microbiol., 21, 1175-1184, 1996.

4. Brender, R.; Janda, J.M. Detection, quantification and stability of the beta-hemolysin of Aeromonas spp. J. Med. Microbiol., 24, $247-$ 250,2002 .

5. Carbonetti, N.H.; Boocha, S.; Parry, S.H.; Vaisanen-Rhen, V.; Korhonen, T.K.; Williams, P.H. Aerobactin-mediated iron uptake by Escherichia coli isolates from human extraintestinal infections. Infect. Immun., 51, 966-968, 1989.

6. Castro-Escarpulli, G.; Figueiras, M.J.; Aguilera-Arreola, G.; Soler, L.; Fernández-Rendón, E.; Aparicio, G.O.; Guarro, J.; Chacón, M.R. Characterization of Aeromonas spp. isolated from frozen fish intended for human consumption in Mexico. Int. J. Food Microbiol., 84, 41-49, 2003.

7. Cetinkaya, Y.; Falk, P.; Mayhall, C.G. Vancomycin-resistant enterococci. Clin. Microbiol. Rev., 13, 686-707, 2000.

8. Coburn, P.S.; Gilmore, M.S. The Enterococcus faecalis cytolysin: a novel toxin active against eukaryotic and prokaryotic cells. Cell. Microbiol., 5, 661-669, 2003.

9. Coque, T.M.; Patterson, J.E.; Steckeeberg, J.M.; Murray, B.E. Incidence of hemolysin, gelatinase and aggregation substance among enterococci isolated from patients with endocarditis and other infection and from feces of hospitalized and community-based persons. J. Infect. Dis., 171, 1223-1229, 1995.

10. Di Martino, P.; Cafferini, N.; Joly, B.; Darfeuille-Michaud, A. Klebsiella pneumoniae type 3 pili facilitate adherence and biofilm formation on abiotic surfaces. Res. Microbiol., 154, 9-16, 2002.

11. Dukta-Malen, S.; Ever, S.; Courvalin, P. Detection of glycopeptide resistance genotypes and identification to the species level of clinically relevant enterococci by PCR. J. Clin. Microbiol., 33, 2427, 1995.

12. Falcón, M.R.; Carvalho, H.F.; Joazeiro, P.P.; Gatti, M.S.V.; Yano, T. Induction of apoptosis in HT29 human intestinal epithelial cells by the cytotoxic enterotoxin of Aeromonas hydrophila. Biochem. Cell Biol., 79, 525-531, 2001.

13. Gunn, B.A.; Dunkelberg, W.E. Jr.; Creitz, J.R. Clinical evaluation of 2\%-LSM medium for primary isolation and identification of coagulase-positive staphylococci. Am. J. Clin. Pathol., 57, 236240, 1972.

14. Guzmàn, C.A.; Pruzzo, C.; LiPira, G.; Calegari, L. Role of adherence in pathogenesis of Enterococcus faecalis urinary tract infection and endocarditis. Infect. Immun., 57, 1834-1838, 1989.

15. Jaeger, K.E.; Ransac, S.; Dijkstra, B.W.; Colson, C.; van Heuvel, M.; Misset, O. Bacterial lipases. FEMS Microbiol. Rev., 15, 29-63, 1994.

16. Joyanes, P.; Pascual, A.; Martinez-Martinez, L.; Hevia, A.; Perea, E.J. In vitro adherence of Enterococcus faecalis and Enterococcus faecium to urinary catheters. Eur. J. Clin. Microbiol. Infect Dis., 19, $124-127,2000$

17. Kreft, B.; Marre, R.; Schramm, U.; Wirth, R. Aggregation substance of Enterococcus faecalis mediates adhesion to culture renal tubular cells. Infect. Immun., 60, 25-30, 1992.

18. Kurl, D.N.; Haataja, S.; Finne, J. Hemagglutination activities of group B, C, D and G streptococci: demonstration of novel sugarspecific cell-binding activities in Streptococcus suis. Infect. Immun. 57, 384-389, 1989

19. Kritish, C.J.; Li, Y-H.; Cvithkovitch, D.G.; Dunny, G.M. Espindependent biofilm formation by Enterococcus faecalis. J. Bacteriol., 186,154-163, 2004.

20. Lowe, A.M.; Lambert, P.A.; Smith, A.W. Cloning of an Enterococcus faecalis endocarditis antigen: homology with adhesins from some oral streptococci. Infect. Immun., 63, 703-706, 1995.

21. Maschieto A.; Martinez R.; Palazzo I.C.V.; Darini, A.L.C. Antimicrobial Resistance of Enterococcus sp. Isolated from the Intestinal Tract of Patients from a University Hospital in Brazil. Mem. Inst. Osw. Cruz., 99(7), 763-767, 2004.

22. Miskin, J.E.; Farrell, A.M.; Cunliffe, W.J.; Holland, K.T. Propionibacterium acnes, a resident of lipid-rich human skin, produces a $33 \mathrm{kDa}$ extracellular lipase encodes by gen A. Microbiology, 143, 1745-1755, 1997.

23. Miyazaki, S.; Ohno, A.; Kobayashi, I.; Uji, T.; Yamaguchi, K.; Goto, S. Cytotoxic effect of hemolytic culture supernatant from Enterococcus faecalis on mouse polymorphonuclear neutrophils and macrophages. Microbio. Immunol., 37, 265-270, 1993.

24. Pelkonen, S.; Finne, J. A rapid turbidmetric assay for the study of serum sensitivity of Escherichia coli. FEMS Microbiol. Lett., 42, 55-57, 1987.

25. Podschun, R.; Ullmann, U. Klebsiella ssp. as nosocomial pathogens: epidemiology, taxonomy, typing methods, and pathogenicity factors. Clin. Microbiol. Rev., 11, 589-603, 1998.

26. Rich, R.L.; Kreikemeyer, B.; Owens, R.T.; LaBrenz, S.; Narayana, S.V.L.; Weinstock, G.M.; Murray, B.E.; Höök, M. Ace is a collagenbinding MSCRAMM from Enterococcus faecalis. J. Biol. Chem. 274, 26939-26945, 1999.

27. Rose, J.M.; Houston, C.W.; Coppenhaver, D.H.; Dixon, J.D.; Kurosky, A. Purification and chemical characterization of cholera 
toxin-across-reactive cytolytic enterotoxin produced by human isolate of Aeromonas hydrophila. Infect. Immun., 57, 1165-1169, 1989.

28. Rowe, G.E.; Welch, R.A. Assay of hemolytic toxins. Methods Enzymol., 235, 657-659, 1994.

29. Shankar, N.; Baghdayan, A.S.; Gilmore, M.S. Modulation of virulence within a pathogenicity island in vancomycin-resistant Enterococcus faecalis. Nature, 417, 746-750, 2002.

30. Scaletsky, I.C.A.; Silva, M.L.; Trabulsi, L.R. Distinctive patterns of adherence of Escherichia coli to HeLa cells. Infect. Immun., 2, 8992, 1984.

31. Stehr, F.; Kretschmar, M.; Kröger, C.; Hube, B.; Schäfer, W. Microbial lipases as virulence factors. J. Mol. Catal., 22, 347-355, 2003.

32. Taylor, P.W. Bactericidal and bacteriolytic activity of serum against gram-negative bacteria. Microbiol. Rev., 47, 46-83, 1983.
33. Vergis, E.N.; Shankar, N.; Chow, J.W.; Hayden, M.K.; Snydman, D.R.; Zervos, M.J.; Linden, P.K.; Wagener, M.M.; Muder, R.R. Association between the presence of enterococcal virulence factors gelatinase, hemolysin, and enterococcal surface protein and mortality among patients with bacteremia due to Enterococcus faecalis. Clin. Infect. Dis., 35, 570-575, 2003.

34. Wakimoto, N.; Nishi, J.; Sheikh, J.; Nataro, J.M.; Sarantuya, J.; Iwashita, M.; Manago, K.; Tokuda, K.; Yoshinaga, M. and Kawano, Y. Quantitative biofilm assay using microtiter plate to screen for enteroaggretative Escherichia coli. Am. J. Trop. Med. Hyg., 71, 687-690, 2004

35. Waters, C.M.; Antiporta, M.H.; Murray, B.E.; Dunny, G.M. Role of the Enterococcus faecalis GelE protease in determination of cellular chain length, supernatant pheromone levels, and degradation of fibrin and misfolded surface proteins. J. Bacteriol., 185, 3613-3623, 2003. 